\title{
Tax Cuts and the Recession in the Massachusetts Fiscal Crisis
}

\author{
Elissa Braunstein ${ }^{1}$ \\ October 2003
}

\section{Research Brief 2003-6}

The disturbing headlines are all too familiar. States across the country are facing the worst fiscal crisis since World War II, and core state services like public education and health care are experiencing drastic funding cuts as a result. Massachusetts is no exception: it had to cut $\$ 1$ billion from the budget last year, and is facing a $\$ 3$ billion budget gap this year. Rather than raise taxes, the state has slashed key services for the majority of the Commonwealth's citizens.

How did we get into this mess? Many believe that the culprit is the recession, or, alternatively, "extravagant" state spending in the 1990s. This research brief summarizes a new analysis using data on Massachusetts state tax revenue. ${ }^{2}$ The main finding is that the major reason for the budget shortfall is legislated cuts in capital gains tax rates, and declines in the yield of the corporate income tax, due to statutory reductions and other factors.

There would be no fiscal crisis today without these policy decisions to cut taxes. If the state had not cut taxes on capital gains, it would have collected about $\$ 4$ billion more in tax revenue. That extra revenue could have been saved in a rainy day fund, and thus absorbed the last three years of spending cuts. ${ }^{3}$ Unless the state restores tax rates to previous levels, we will continue to experience serious budget shortfalls, and more cuts to essential services.

\footnotetext{
${ }^{1}$ Elissa Braunstein is an Assistant Research Professor at PERI.

2 A much more detailed analysis can be found in the PERI research paper entitled, "Tax Cuts and the Recession in the Massachusetts Fiscal Crisis" by Elissa Braunstein, accessible on the web: http://www.umass.edu/peri/research.html.

${ }^{3}$ If, indeed, state government had elected to bank the extra revenue, they would have had to raise the cap on the state's rainy day fund.
} 


\section{The Massachusetts Fiscal Crisis}

The state budget crisis followed closely on the heels of the recent recession. In 2001, real personal income in Massachusetts declined -0.03 percent, and in 2002, -0.18 percent. State tax collections outweighed this decline: In 2002, real state government tax collections declined by about 13.8 percent, from $\$ 17$ billion in 2001 to $\$ 14.8$ billion in 2002 .

What perhaps may be more familiar to most state residents is the impact of these declines on the state's budget. In fiscal year 2002, the final budget approved by the legislature was about $\$ 600$ million less than the original House and Senate recommendations (MBPC 2003). For fiscal year 2003, the deficit was $\$ 2.7$ billion, inducing legislators to cut the state budget by about $\$ 1$ billion (TEAM 2002). The shortfall for the fiscal 2004 budget is about $\$ 3$ billion. About $\$ 1.7$ billion will be covered by lower spending. All told, Massachusetts residents have seen about $\$ 3$ billion in spending cuts since the fiscal crisis began.

\section{Is Spending the Problem?}

Some argue that the state is a profligate spender, and that the budget crisis will instill fiscal discipline and enhance government efficiency. But state spending growth has actually slowed in the last decade. The real annual growth rate of state spending between 1991 and 2002 was 2.0 percent, while personal income rose an average of 2.6 percent annually. So state spending is actually declining as a proportion of income earned: in 1991, state expenditures were 9.7 percent of personal income; in 2002, they were 9.1 percent. $^{4}$

\section{Measuring the Impact of Tax Cuts and the Recession}

To assess the relative roles of tax cuts and the recession in the fiscal crisis, I will evaluate Massachusetts state government tax revenue during the boom and bust years of 1996-2002. I focus on tax revenue, as opposed to expenditure, because the central issue I want to address is: would the fiscal crisis have been averted without the formidable tax cuts of the late 1990s? To answer this question, I compare three different aspects of the crisis. First, I isolate the impact of tax cuts, beginning in the early boom with the implementation of the first capital gains tax cut in 1996, and ending in 2002. If the state had collected and then saved this revenue, it could have used these funds to deal with the crisis. Hence, measuring the effect of tax cuts between 1996 and 2002 really measures a missed opportunity that would have ensured the state against the budgetary effects of recession. Second, I isolate the impact of the recession in 2001 and 2002 on state tax revenue, and then compare this amount to the impact of the 1996-02 tax cuts. The resulting comparison shows the relative importance of tax cuts versus the recession for the state's tax revenue. And last, I use spending cuts in fiscal years 2002-04 as an objective measure of the crisis - a yardstick by which to gauge the impact of tax cuts and the recession.

To make these comparisons, I look at four different streams of state tax revenue: personal income, capital gains, corporate income and sales taxes, which together represented 93 percent of

\footnotetext{
${ }^{4}$ According to the National Bureau of Economic Research, the last two national business cycle troughs occurred in March 1991 and November 2001. Hence, comparing state spending in fiscal years 1991 and 2002, both of which featured a business cycle trough, suggests that I am capturing state spending at similar points in its economic history.
} 
state tax revenue in 2002. I estimate two sources of change for each type of tax. The first, which I will call "business cycle effects," measures the impact of the economy. It captures how changes in economic growth - boom versus bust - affect tax revenue.

The second measure, "effective tax cuts," captures the impact of changes in effective tax rates, while assuming a consistent rate of economic growth. An effective tax rate expresses actual tax revenue as a percent of income. ${ }^{5}$ Effective tax rates are a measure of taxation that, when considered over time, capture broad changes in the structure of taxation. These might include changes in the statutory tax rate, the effectiveness of the state's tax collection efforts, or the ability of taxpayers to avoid paying taxes. All of these factors will change the amount of tax revenue that the state collects, and thus alter the effective tax rate. ${ }^{6}$

Starting off with the role of the business cycle, the basic intuition behind isolating these effects is fairly simple: by multiplying the increase in income for each year (relative to the base year 1995) by the prevailing effective tax rate, we get the change in tax revenue due solely to changes in income, or the business cycle.

Table 1 details the results of looking at the negative growth years of 2001 and 2002. By a wide margin, the biggest recession-based declines in state tax revenue were in capital gains taxes ( $-\$ 1$ billion) and corporate income taxes ( $\$ 476$ million). In total, the recession was responsible for a decline of $\$ 1.5$ billion in state tax revenue. Figure 1 compares that amount to the state's spending cuts in fiscal years 2002-04, about $-\$ 3$ billion. Clearly, the recession is at most responsible for one-half of the spending cuts.

Table 1. The Effects of Recession on Tax Revenue, 2001-2002 (millions \$2002)

\begin{tabular}{|c|c|c|c|c|c|}
\hline & $\begin{array}{l}\text { Personal } \\
\text { Income }\end{array}$ & $\begin{array}{l}\text { Capital } \\
\text { Gains }\end{array}$ & $\begin{array}{l}\text { Corporate } \\
\text { Income }\end{array}$ & Sales & Total \\
\hline $\begin{array}{l}\text { Effect on State Tax } \\
\text { Revenue, 2001-02 }\end{array}$ & $-\$ 18$ & $-\$ 1,025$ & $-\$ 476$ & $-\$ 13$ & $-\$ 1,532$ \\
\hline $\begin{array}{l}\text { Percent of Spending } \\
\text { Cuts, FY2002-04* }\end{array}$ & $0.6 \%$ & $34.2 \%$ & $15.9 \%$ & $0.4 \%$ & $51.1 \%$ \\
\hline
\end{tabular}

*Spending cuts for FY2002-04 equal - $\$ 3$ billion.

Source: Author's calculations. All tax data (with the exception of capital gains) were drawn from the Census Bureau's quarterly figures on state tax revenue. Capital gains data are from the Office of Tax Policy Analysis at the Massachusetts Department of Revenue. And personal income data is from the U.S. Bureau of Economic Analysis.

\footnotetext{
${ }^{5}$ For personal income taxes, the income measure used is personal income; for capital gains taxes, it is capital gains realizations; for corporate income taxes, it is total profits for corporations filing in Massachusetts; and for sales taxes, it is personal income.

${ }^{6}$ One potential problem with using effective rates is that changes in income may change effective rates. In that case, the effective tax cut measure might also capture some business cycle effects. As discussed in Appendix F of the more in-depth research brief, this is only an issue for personal income tax rates, and so changes in statutory rates were used instead.
} 


\section{Figure 1. The Recession and the State's Spending Cuts}

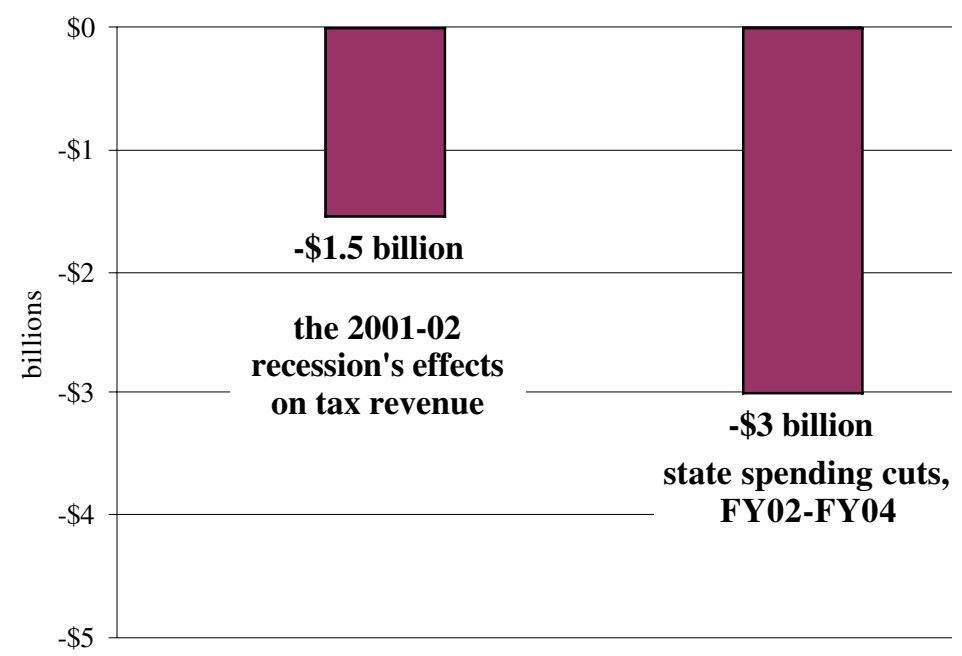

Note: Recession's effects are in \$2002; state spending cuts are in nominal terms.

Source: Author's calculations based on data described in Table 1.

What about tax cuts? Similar to the business cycle estimate, we can isolate the impact of effective tax cuts by holding income constant at its inflation-adjusted 1995 level, and multiplying that by the difference between the effective tax rate, and some reference or base tax rate. The base tax rate used is the average effective tax rate by type of tax between 1993 and 1995, as using an average that spans several years smoothes out any annual volatility.

Figure 2 details the results by type of tax. Looking at capital gains tax revenue first, we see that effective tax cuts on capital gains were responsible for a $\$ 1.5$ billion decline in state tax revenue between 1996 and 2002. This decline reflects a change in Massachusetts tax law which dramatically lowered the tax rate on long-term capital gains (defined as assets held for more than one year). Prior to the tax cut in 1996, long-term assets, after a 50 percent exclusion, were taxed at 12 percent. The tax cut was phased in over a period of years, as reflected in the gradual decline of the effective tax rate. Once fully phased in, capital gains tax rates would range from five percent for assets held one to two years, to zero for assets held more than six years. Tax legislation in 2002, passed in response to the fiscal crisis, backpedaled on this legislation, taxing long-term gains at the same rate as other types of income.

What if lawmakers had not passed the 1996 tax cut? If effective rates had remained at their 1993-95 levels, and the economy had performed as it did (allowing the growth in capital gains realizations to stand), the state government would have collected about $\$ 9.6$ billion in capital gains taxes between 1996 and 2002 . This is $\$ 4.4$ billion more than they actually collected. If the state had put this money away into a rainy day fund, it would have had enough to cover the spending cuts in fiscal years 2002-04. The 1996 capital gains tax cut essentially legislated the state out of much of the tax revenue it might have collected from the stock market boom. $^{7}$

\footnotetext{
${ }^{7}$ Higher rates would, of course, dampen asset sales and therefore lower capital gains tax revenue somewhat.
} 
Figure 2. Effective Tax Cuts by Type of Tax, 1996-2002

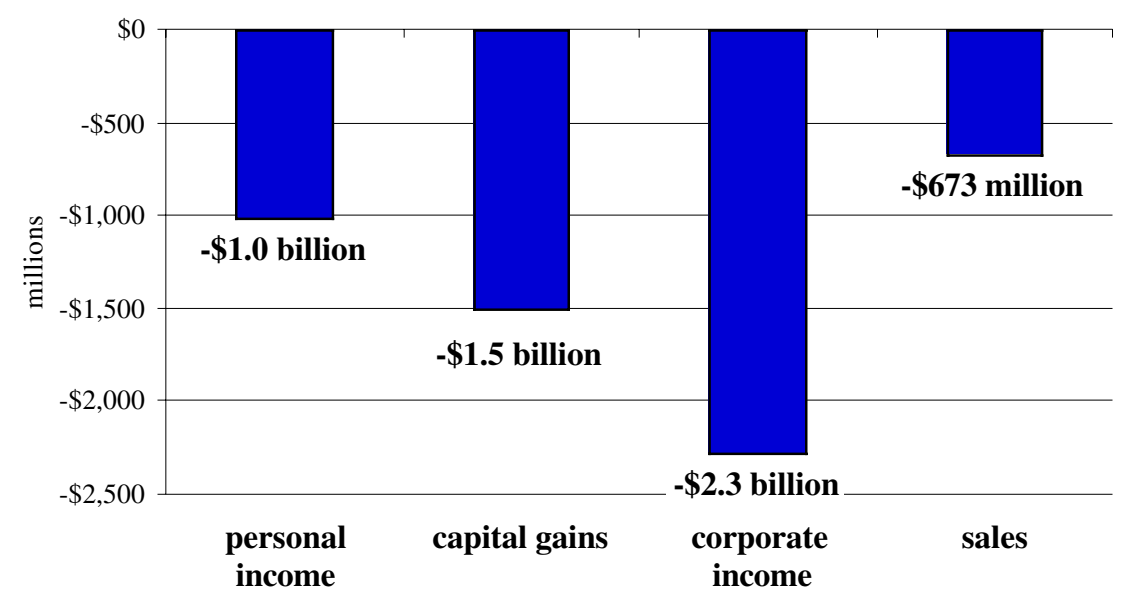

Source: Author's calculations based on data described in Table 1.

The second major source of the decline in state tax revenue is the effective tax cut in corporate income taxes, which caused a \$2.3 billion decline in taxes between 1996 and 2002. This amounts to 25 percent of corporate tax revenue during this period. The underlying reasons for these substantial effective cuts are not as straightforward as those for capital gains.

First, there were a number of statutory changes to corporate tax law that decreased tax revenue in the 1990s. Of particular significance is the institution of the single sales factor apportionment formula, which taxes corporate profits based on what proportion of their sales take place in Massachusetts. For corporations with large state payrolls and limited state sales, a sales-only apportionment formula is a significant tax break because then only a small proportion of their profits is subject to state income taxes.

Second, there is simply an increasing incidence of tax evasion. Corporations are using ever more complex strategies to shift profits out of Massachusetts and into states where they either will not be taxed, or will be taxed at a lower rate. This is part of a federal trend, and one does not have to go far to find ample evidence of this type of activity. Between 1995 and 2000, inflation-adjusted federal corporate income taxes grew an average of two percent a year; the annual average for state and local corporate tax revenue actually declined by -0.12 percent during the same period. ${ }^{8}$ In addition to corporations actively shifting profits to evade taxes, another key reason for this decline is inter-state tax competition. Changing apportionment formulas to attract business is a common problem, in many instances encouraging or even initiating the practice of profit-shifting to evade state taxation.

As for personal income tax revenue, changes in the structure of taxes resulted in a $\$ 1$ billion decline in personal income tax collections between 1996 and 2002. This amount reflects the significant statutory cuts between 1999 and 2002. ${ }^{9}$

\footnotetext{
${ }^{8}$ Data is from the National Income and Product Accounts.

${ }^{9}$ These changes include a doubling of personal exemptions, fully phased in by 1999. And in tax year 1999, tax rates on interest and dividend income were reduced from 12 percent to 5.95 percent (the same as wage income). In 1999 , legislation was passed to further reduce taxes on both wage and interest and dividend income: in 2000, the rate
} 
Lastly, sales tax revenue declined by $\$ 673$ million due to effective tax cuts. This result is to be expected in light of the natural erosion in the sales tax base that takes place as services and internet sales grow in proportion to the rest of the economy. It indicates that state governments should reconsider the sales tax base if they are determined to maintain its viability as an ongoing source of state revenue.

Figure 3 summarizes the effective tax cut results, as well as repeats the impact of the recession and the size of the state's recent spending cuts for comparison. Recall that the reason for comparing these three results is twofold. First, isolating the effective tax cuts during 1996-02 is based on the idea that the state could have put these extra revenues into a rainy day account. They would then be able to draw down these funds to cover the budget cuts. Second, comparing these cuts with the impact of the recession on tax revenue (business cycle effects for 2001 and 2002) illustrates that the recession was only partly responsible for the budget shortfalls.

In total, effective tax cuts were responsible for a loss of $\$ 5.5$ billion between 1996 and 2002. Nearly all of that decline -70 percent - was due to tax cuts for capital gains ( $\$ 1.5$ billion) and corporate income ( $\$ 2.3$ billion). Personal income tax cuts cost the state $\$ 1$ billion. If the revenue had been put into a rainy day fund, this amount comfortably covers the spending cuts in fiscal 2002-04 (\$3 billion), with $\$ 2.5$ billion left over to cover future budget gaps. What about the recession? The loss in tax revenue due to the recession was $\$ 1.5$ billion, certainly a sizeable amount but only one-half of the spending cuts for the last three fiscal years. Clearly, the state is in its current crisis not primarily because of the recession, but because of the tax cuts it implemented in the late 1990s.

\section{Figure 3. Tax Cuts and the Recession}

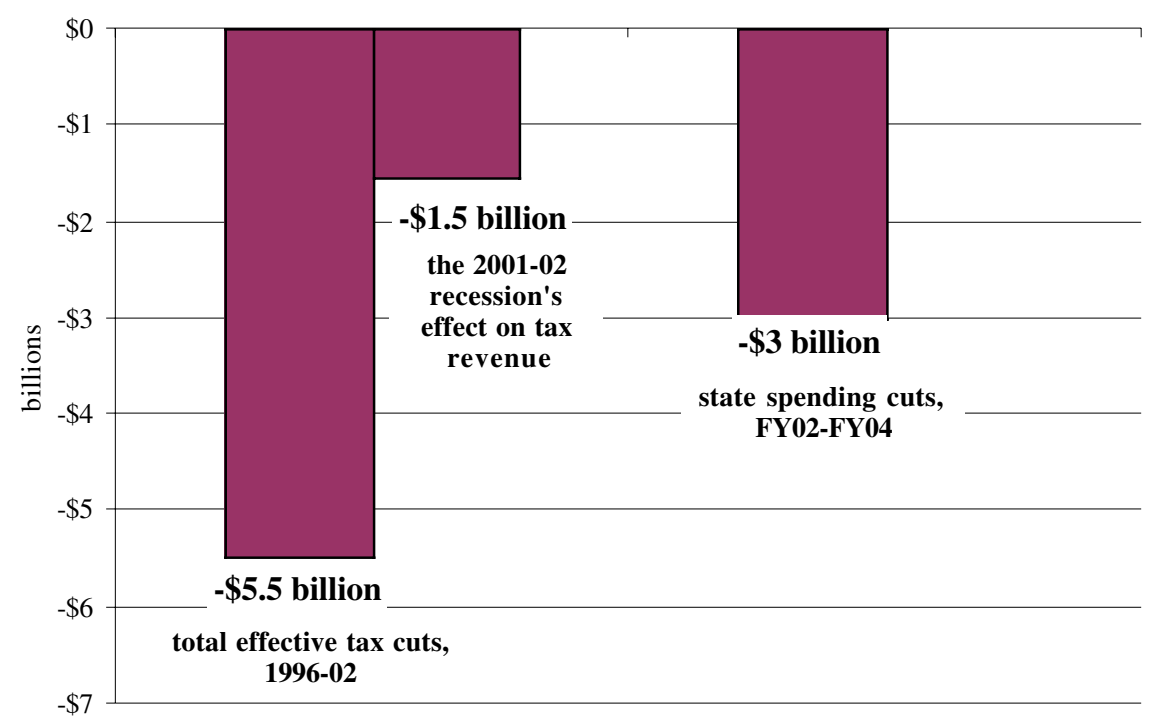

Note: Recession and effective tax cut effects are in \$2002; state spending cuts are in nominal terms. Source: Author's calculations based on data described in Table 1.

would decline to 5.85 percent; in 2001, to 5.8 percent; and in 2002, to 5.75 percent. In 2000, legislation lowered these rates even further: in 2001, they would decline to 5.6 percent; in 2002, to 5.3 percent; and in 2003, to 5.0 percent. As a result of the fiscal crisis, rates were frozen at 5.3 percent in 2002. 


\section{Policy Options for the Future}

From the analysis above, we know that corporations and the wealthy have benefited enormously from the tax cuts of the 1990s. As a result, the state has been driven into a serious fiscal crisis, and legislators have chosen by and large to cut state spending to deal with it. Who ultimately pays for these cuts? The answer is consumers of state services, who include: the poor and disabled; the elderly; children in school or in need of childcare assistance; state college system students; and state employees. The list touches on most state citizens, but is heavily weighted towards children, the poor, the elderly, and the disabled. Such a contrast - the contrast between those benefiting and those paying for the tax cuts of the 1990s - could not be starker.

Are there better times ahead? Not without policy changes. When the economy recovers, tax revenue, given currently legislated effective tax rates, cannot rise enough to cover the continuing budget shortfall. Thus, the state's government must reassess its seemingly unshakable commitment to tax cuts that largely benefit the wealthy. Restoring tax rates on income to their 1995 levels, and rolling back corporate tax breaks, should be considered immediately. ${ }^{10}$ In 2002, the legislature made some progress on this front by taxing long-term capital gains the same as other types of income, but there is still a ways to go. Consider the following: if effective tax rates were returned to their base rate levels (the average effective tax rate between 1993 and 1995), assuming no income growth between 2002 and 2003, the state would collect an additional $\$ 2.4$ billion in taxes, as indicated in Figure 4. ${ }^{11}$ Most of that revenue would come from personal income taxes ( $\$ 1.4$ billion). But even with zero growth, restoring rates on corporate income would bring in an additional $\$ 576$ million. This amount would go a long way towards covering the projected budget gap for fiscal 2005, between $\$ 2$ and $\$ 3$ billion.

\section{Figure 4. Additional tax revenue in 2003 if we return to 1993-1995 tax rates}

Total additional tax revenue: $\$ 2.4$ billion

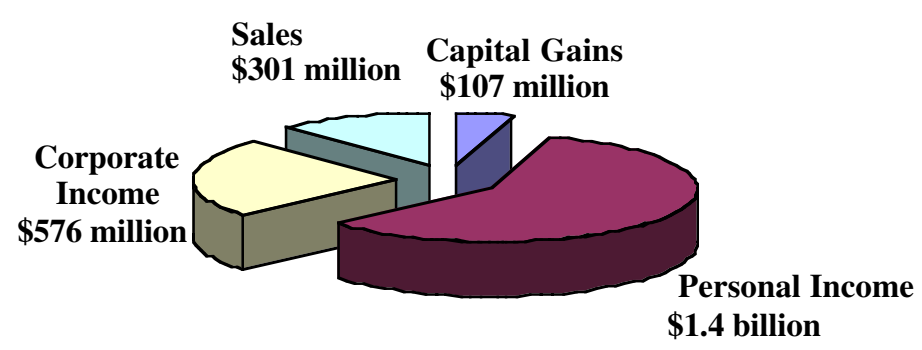

Source: Author's calculations based on data described in Table 1 and in the text.

\footnotetext{
${ }^{10}$ McLynch and St. George (2003) discuss in detail the types of corporate tax reforms the state should consider.

${ }^{11}$ For capital gains, the amount listed here is the difference between projected capital gains tax revenue after the 2002 rollback, and revenue if rates were the same as the base period, 1993-1995.
} 
To guard against future crises, we need to curtail the tendency of state legislators to cut taxes in boom times, only to reluctantly raise them during recessions as budgets get squeezed. There is considerable evidence that state governments do this; a strong correlation exists between economic growth and tax cuts (McGranahan 2002). It makes much more sense to maintain tax rates in boom times, thus enabling states to bank excess revenues in rainy day funds. These could then be used to smooth out spending during recessions, when tax revenue is down but the state cannot borrow to meet operating expenses, and spending cuts have heavy impacts. If this had been the case in Massachusetts, there would be no fiscal crisis today.

\section{References}

Firestone, David. 2003. "With Plan for State Aid, Senate Republicans Gain Crucial Democratic vote on Tax Cut." The New York Times, Section A, p. 33, May 15.

Massachusetts Budget and Policy Center. 2003. "The Massachusetts Budget Crisis, Sources and Solutions.” August 5.

McGranahan, Leslie. 2002. "Unprepared for boom or bust: Understanding the current state fiscal crisis." Economic Perspectives Q3: 2-25. Federal Reserve Bank of Chicago.

TEAM Education Fund. 2002. Budget Monitor. TEAM Education Fund, August 9. 